PERSPECTIVA TEOLÓGICA ADERE A UMA LICENÇA CREATIVE

COMMONS ATRIBUIÇÃO 4.0 INTERNACIONAL - (CC BY 4.0)

DOI: $10.20911 / 21768757 v 50 n 2 p 307 / 2018$

\title{
DA EUROPA À AMÉRICA LATINA: A VULNERABILIDADE COMO LOCUS THEOLOGICUS
}

From Europe to Latin America: vulnerability as a locus theologicus

Cleusa Caldeira *

RESUMO: O contexto hodierno está marcado pela violência intersubjetiva em escala planetária, que coloca em risco o futuro da humanidade e do planeta. Diante disso, somos levados a perguntar: haverá esperança para a humanidade? Onde está Deus diante do sofrimento do inocente? Estas questões requerem da teologia uma aproximação ao real, sem cair, contudo, na tentação de apelar para um resgate milagroso ou ficar paralisada frente ao nada. Antes, ela deverá pensar na contribuição do cristianismo entre a derrocada do sujeito moderno e a emergência da vulnerabilidade. Depara-se, pois, com a crise do humanismo moderno e a abertura à uma nova hermenêutica do humano como possibilidade de encontrar na kénosis outra maneira de ser-no-mundo em tempos de fragmentos. Nesse horizonte, apresentamos duas versões da narrativa cristã que tematizam outro modo de ser-no-mundo, na assunção da vulnerabilidade constitutiva da subjetividade, como caminho de redenção.

PALAVRAS-CHAVE: Pós-modernidade. Niilismo. Narrativa cristã. Subjetividade vulnerável.

ABSTRACT: Today's context is marked by intersubjective violence on a planetary scale, which keeps the future of the humanity and the planet at risk. As a result, we are compelled to question: will there be a hope for the humanity? Where is God amidst the suffering of the innocents? These questions require from theology, a true approximation to the reality, without falling, however, into the temptation to look for a miraculous rescue or to be paralyzed in the pain of emptiness. Rather,

* Pontifícia Universidade Católica do Paraná, Curitiba, Brasil. 
such questions should reflect upon the Christian contribution which throws light on the destructiveness of the modern subject and the emergence of the vulnerability. One finds, therefore, with the crisis of modern humanism and the openness to a new hermeneutic of the human, as a possibility of finding meaning in the kenosis, a different way of being-in-the-world in times of fragmentations. In this perspective, we present two versions of the Christian narrative that thematisize the other way of being-in-the-world, in the assumption of the constitutive vulnerability of the subjectivity, as a path of redemption.

KEYWORDS: Postmodernity. Nihilism. Christian Narrative. Vulnerable Subjectivity.

\section{Introdução}

$\mathrm{O}$ contexto paradoxal em que nos encontramos, com o esgotamento da religião e o concomitante retorno do religioso, está marcado pela derrocada do sujeito moderno e pela emergência da vulnerabilidade. Existem, de fato, inúmeras interpretações desta vulnerabilidade, da mesma forma que multiplicam os contextos e as subjetividades. $\mathrm{O}$ que se deduz é que a nova subjetividade, marcada que está pela aguda consciência da finitude, da culpabilidade e da possibilidade de redenção que chega pela alteridade amorosa, torna-se o novo locus theologicus. E, no limiar do terceiro milênio, a teologia pós-moderna surge, em meio aos escombros da modernidade e da derrubada do Si-mesmo, como "um 'arco-íris' de experiências e linguagens", com a intensão de balbuciar o Mistério divino em uma pluralidade de experiências e contextos (MENDOZA, 2015a, p. 311). Nesse horizonte, este texto se propõe a apresentar duas versões da narrativa cristã em tempos de fragmentos, como tentativas de dizer a especificidade da fé cristã.

A primeira narrativa nascida na Europa, mais especificamente em terras lusitanas, assinada pelo teólogo João Manuel Duque, inscreve-se no debate do pós-humano e da cibercultura. Nela o autor propugna uma resposta teológica para o problema do sujeito autônomo obcecado por superar sua finitude constitutiva, que aqui se apresenta num pós-humanismo como pretensão de superar os limites do corpo sob a máscara da virtualidade (DUQUE, 2016b, p. 205-206) ${ }^{1}$. A antropologia teológica do teólogo português, influenciado que está pelos filósofos Paul Ricoeur (DUQUE, 2015, p. 71-78) e Emmanuel Levinas, passa pela filosofia da hospitalidade (DUQUE, 2017b, p.195-213), na qual a

\footnotetext{
${ }^{1} \mathrm{O}$ campo da virtualidade discute a questão do humano na relação entre realidade e virtualidade. Ele pergunta sobre a simulação do real e suas consequências sobre a humanidade dos humanos. Nesse contexto, o conceito de virtualidade não se opõe ao real, antes ele fala daquilo que não é atual.
} 
hospitalidade é pensada como um modo constitutivo da subjetividade relacional (DUQUE, 2014, p. 149-160).

A segunda narrativa, por sua vez, consiste na descrição de uma teologia com rosto latino-americano, que emerge como "escuta do clamor das vítimas", mais especificamente das resistências epistêmicas e espirituais dos sobreviventes no contexto de exclusão global. Desenvolvida pelo teólogo mexicano Carlos Mendoza Álvarez, essa teologia assume, de modo inédito no continente, o niilismo pós-moderno como locus theologicus (CALDEIRA, $2017 b$, p. 810). Nesse pathos cultural do niilismo pós-moderno em intersecção com o pensamento antissistêmico ${ }^{2}$, o teólogo mexicano afirmará que a América Latina tem algo a dizer à Europa niilista: Deus escuta o clamor da vítima. De maneira a afirmar que fora da verdade perseguida pela vítima perdoadora ${ }^{3}$ não existe redenção possível para a humanidade que se debate entre rivalidade e doação (MENDOZA, 2013, p. 192-203).

Segundo a teoria do desejo mimético de René Girard, o desejo humano se constitui através da mediação de um terceiro, que serve como referência de significação e sentido, isto é, o duplo mimético (GIRARD; CHANTRE, 2011, p.173). Neste horizonte, podemos afirmar que Carlos Mendoza e João Duque constituem um duplo mimético, que a nós coube a feliz tarefa de colocar em diálogo. Esse encontro - não apenas literário - poderá contribuir para a construção da identidade estruturada na gratuidade, isto é, quando a subjetividade em sua constitutiva vulnerabilidade supera a dialética para viver a existência em permanente doação.

Enfim, desejamos apresentar à leitora e ao leitor essas duas criativas teologias que se propõe a dizer Deus e o humano num contexto em que a teologia é fortemente criticada por tornar-se cúmplices dos sistemas de totalidade, tendo de responder à pergunta: "Onde está Deus diante do sofrimento humano"?

Expor, pois, duas teologias distintas significa assumir a contextualização da verdade e, assim, reafirmar que não podemos ter a pretensão de uma

\footnotetext{
${ }^{2} \mathrm{O}$ pensamento antissistêmico está ligado ao movimento zapatista mexicano, que cunhou a expressão "a partir de baixo e da esquerda" para recuperar a lógica da pobreza elegida pela filosofia do bem viver. Carlos Mendoza, por sua vez, em glosa ao pensamento antissistêmico, usa a expressão "a partir de baixo e do reverso" para justificar o processo fenomenológico da subjetividade exposta e niilista (MENDOZA, 2015a, p. 56).

${ }^{3} \mathrm{O}$ conceito da "vítima perdoadora" (The forgiving victim), designa a original intuição do teólogo britânico James Alison em sua "recepção criativa" da teoria mimética de René Girard, para falar da aparição do Crucificado-Ressuscitado como aquela densa presença que revela o amor além da morte e, sobretudo, o desmantelamento do sistema que crucifica os inocentes por meio do desejo mimético violento. Na teologia de Carlos Mendoza, por sua vez, a aparição do Crucificado-que-vive, revela a "(im)potência potente" como núcleo da subjetividade e, assim, inaugura uma nova ontologia relacional marcada pela gratuidade. Ver: CALDERIA, Cleusa. "Tempo messiânico e sacramentalidade da subjetividade vulnerável na obra de Carlos Mendoza Álvarez". Tese de doutorado em Teologia, pela Faculdade jesuíta de Filosofia e Teologia (FAJE), Belo Horizonte: 2017, p. 242.
} 
visão totalizadora do real. Antes a racionalidade pós-moderna permite apenas ensaiar um balbucio do divino, respeitando os outros pensamentos e buscando encontrar pontos de convergência, para que haja comunhão na diferença.

\section{Corporeidade e vulnerabilidade}

João Manuel Duque é professor catedrático na Universidade Católica Portuguesa. Ele nasceu em 25 de março de 1964 em Monção, Portugal. Doutorou-se em Teologia pela Sankt Georgen de Frankfurt. Músico e teólogo leigo, João Duque é autor de vários livros e artigos científicos, destacamos seus principais livros: "Dizer Deus na pós-modernidade" (2003), "Homo credens" (2002) "O excesso do dom" (2004), a "Transparência do conceito" (2010), "Para o diálogo com a pós-modernidade" (2016) e "El Dios ocultado" (2017).

No contexto do pós-humanismo e da cibercultura - apropriando-se das contribuições de Kurt Appel - o teólogo português João Duque desenvolve sua teologia hermenêutica do humano: o Ecce Homo, a humanidade encarnada numa pessoa concreta (eis - eis-me aqui) e não apenas pré-definida como essência. Trata-se de um texto cujo conteúdo foi exposto por João Duque no Simpósio Internacional de Filosofia e Teologia da Faculdade Jesuíta, em 2014 . Descrevemos, pois, dois aspectos dessa hermenêutica do humano: a) Utopias do ilimitado; b) Corpo e vulnerabilidade.

Numa cultura que glorifica o êxito e a felicidade e que se torna cega ao sofrimento dos outros, pode a recordação de que, no centro da fé cristã, se encontra um Cristo sem êxito, sofredor e que morre na vergonha, abrir aos humanos os olhos para a verdade (MOLTMANN, 1985, p. 243).

A figura do Ecce Homo é deveras sintomática. Na sua paradoxal presença dá-se uma revelação do humano, em várias dimensões. Revela-se, é certo, o que os humanos podem fazer, desfigurando o outro humano; mas também se revela a condição vulnerável do humano e a sua presença especial nas vítimas desfiguradas. No contexto de uma cultura mediática global, essa revelação é um sinal que aponta para uma antropologia anti-gnóstica (DUQUE, 2016a, p. 163-182). Esta assenta na limitação corpórea como condição de possibilidade do próprio humano, ao arrepio de certas utopias pós-humanas contemporâneas, nomeadamente no contexto da cibercultura.

\footnotetext{
${ }^{4}$ Nesta primeira parte do artigo, todas as traduções foram realizadas por João Duque.
} 


\subsection{Utopias do ilimitado}

O corpo encontra-se sob suspeita, numa cultura a caminho do cyborg. Essa suspeita é a suspeita de sempre, que vê na condição corpórea o principal inimigo da realização do humano perfeito. Na busca dessa perfeição, o corpo é sacrificado: na medida em que é forçado, manipulado, metamorfoseado, mas também na medida em que chega a ser eliminado ${ }^{5}$. "Numa tecnologia que procede essencialmente por meios imateriais, parece ser imperioso criar e animar corpos sem carne formas de vida que devem pois reinventar o corpo perfeito (que a teologia sempre prometeu), e que, no limite, será inteiramente imaterial, todo ele alma, ou animação" (CRUZ, 2000, p. 366) .

A alma deste processo é, sem dúvida, a utopia da superação dos limites, considerados colocados pela própria constituição material, que no corpo ganha a sua forma concreta. Assim, em última instância, a vulnerabilidade corpórea é considerada o principal impedimento à realização da perfeição humana. Entendido o humano como inevitavelmente corpóreo, a sua perfeição coincidiria com a sua própria superação, ou seja, como o pós-humano propriamente dito.

Teologicamente, a pretensa superação do limite imposto (e garantido) pelo corpo, pode ser identificada com o ato do próprio pecado original, na medida em que o ser humano pretende, pela manipulação de si mesmo e do mundo, abandonar a sua condição finita: tornar-se como Deus, comendo (dominando) a árvore do conhecimento (de si e do todo). O teólogo austríaco Kurt Appel interpreta assim o processo originário, que conduz ao niilismo do humano, na leitura que faz dos primeiros capítulos do Gênesis. Segundo ele, o ser humano perde o manto protetor constituído pela própria indisponibilidade, no momento em que é aprisionado no horizonte meramente humano, tornando-se consequentemente manipulável ('comestível') (APPEL, 2015, p. 28).

A nudez niilista daí resultante - primeira consequência da primeira pretensão de infinitude sem limite, pelo domínio de si - adquire, contudo, um novo manto protetor, este já não originário mas derivado, uma espécie de simulacro daquele: trata-se da própria morte, enquanto limite que "restaura" a condição humana limitada e, por isso, vulnerável, não plenamente manipulável. "Depois da perda do manto de luz, a morte torna-se o segundo manto do ser humano... Por essa razão, a morte simula aquele limite originário" (APPEL, 2015, p. 29). Mas esta defesa última do humano

\footnotetext{
${ }^{5}$ Veja-se a representação artística deste fenómeno na obra de Stelarc, baseada no caráter obsoleto do corpo real.

${ }^{6}$ Para João Duque, discutível é, aqui, a "promessa" da teologia. Mas o autor prefere não a discutir neste momento.
} 
contra si mesmo é trágica, porque ambivalente, pois também implica a desfiguração do humano. O que conduz a renovadas procuras - tentações e tentativas - de superar a morte e, com isso, de anular o manto que ainda resta. Pode interpretar-se assim o processo niilista do terror (como no nazismo), mas também ao processo niilista do virtual.

A última machadada desta maquinaria atinge a proteção divina da mortalidade: também essa deve ser sacrificada à referida ausência de temporalidade e a visão do futuro aponta para que a vida seja substituída pelo círculo cibernético. Desse modo cai a máscara da morte humana, que é trágica, mas que ainda o conseguia proteger; no seu lugar não surge a vida, mas o puro espelho do nada virtual (APPEL, 2015, p. 44).

Neste ponto parece vir a desembocar certa linha de leitura do pós-humano cibercultural, fazendo convergir a questão para a dimensão da corporeidade e, nessa, a da vulnerabilidade do humano, especificamente representada na sua condição mortal. Esta, contudo, espelha-se na dinâmica relacional das vulnerabilidades. É nesse ponto que uma teologia pós-moderna ${ }^{7}$ - pós-niilista - poderá explorar a categoria da vulnerabilidade como base da humanidade e de um novo humanismo cristão, orientado para o símbolo do sétimo dia festivo, mas não idealista nem virtual.

O ser humano festeja, portanto, ao sétimo dia e no encontro com Deus, a sua diferença em relação a Deus e em relação a si mesmo, como projeção; diferença que, para além disso, se encontra já anunciada corporeamente pela dualidade entre homem e mulher. Ligado a isso encontra-se um momento de indisponibilidade e de contingência, através do qual o ser humano se torna vulnerável. Neste sentido, a festa do sétimo dia poderia ser definida como festa anti-faraónica da contingência e da criaturalidade vulnerável, ou então como festa da transição para a esfera do indominável, cuja proteção trágica é constituída pela morte (APPEL, 2015, p. 30).

\subsection{Corpo e vulnerabilidade}

Interpretando o limite articulado corporeamente como dado fundamental da humanidade, que protege cada humano da destruição - por si mesmo ou pelo outro - através da pretensão de domínio pela superação do corpo, podem explorar-se elementos dessa corporeidade que, exprimindo a vulnerabilidade da nossa condição, exprimem também a dimensão salvífica dessa vulnerabilidade. Desses elementos, pode salientar-se a corporeidade como condição de exposição e de hospitalidade.

De fato, o corpo próprio e a sua autoconsciência são sempre já efeito de uma exposição ao outro, que me torna "eu", enquanto ser que responde, no corpo e na consciência, a esse outro que me assalta. Eu sou sempre já

\footnotetext{
${ }^{7}$ Sobre o assunto, cf. Duque, J. M. Dizer Deus na pós-modernidade. Lisboa: Alcalá, 2003.
} 
o espaço e o tempo do outro em mim mesmo. Porque não há um "eu" sem um outro prévio. Não há também experiência do corpo próprio, sem experimentar o outro nesse corpo. Ser eu é ser sempre já afetado pelo outro; é ser/estar exposto.

Ao mesmo tempo, a minha exposição ao outro corresponde a uma exposição do outro a mim. Porque o outro, na sua vulnerabilidade corpórea, é sempre já um ser exposto à minha responsabilidade. Sendo assim, a minha identidade deve-se, também, ao modo como eu sou para o outro. Eu - e não outro qualquer e não todos, em geral - sou o que sou, na medida em que, na minha subjetividade corpórea, estou para o outro. Assim, a identidade joga-se sempre, na relação corpórea a uma alteridade constitutiva (DUQUE, 2011, p.15-29).

Ora, a consideração de mim como corpo exposto ao outro equivale à realização da hospitalidade como fonte primeira da identidade humana (DUQUE, 2014, p. 149-160). Eu sou aquele que, na minha unicidade irrepetível, acolho o que me é estrangeiro, na sua unicidade irrepetível e na sua estranheza constitutiva - identificada na sua incômoda presença corporal. Nenhum meio comum - como uma espécie de nação, hoje transformada em rede tecnológica em que todos somos reduzidos à comum identidade de cibernautas - pode dispensar a responsabilidade concreta do hospedeiro em relação ao seu hóspede. Nada pode, pois, simular a minha identidade corpórea como lugar para cada outro real que se me expõe. Estamos, por assim dizer, perante uma teologia política da encarnação, que faz da carne exposta de cada um a mais profunda e mais absoluta interpelação à minha ação responsável, de acolhimento, por isso marcante de uma política para além e anterior à polis - de uma política constituída pela pura inter-humanidade. $\mathrm{O}$ humano define-se, pois, neste gesto primordial de inter-humanidade, e não no conceito de si mesmo como absoluto ou na inserção num território ou numa rede.

Conclui-se que a vulnerabilidade do corpo exposto e hospitaleiro é, pois, a encarnação do humano. O Ecce Homo contradiz a ideologia do êxito pela superação dos limites, para nos reconduzir às manifestações concretas da vulnerabilidade, como caminho de realização salvífica: os pobres, os desfigurados, os idosos, etc.

\section{Subjetividade vulnerável e a vítima perdoadora}

Nascido em Puebla em 24 de abril de 1961, México, o frei dominicano Carlos Mendoza Álvarez aparece como o maior expoente da teologia da libertação em contexto pós-moderno. De forma inédita no continente, ele estabelece um fecundo diálogo com o niilismo pós-moderno e, assim, situa 
a subjetividade (pós)moderna como lugar teológico. Autor de dezenas de livros e uma centena de artigos científicos e capítulos de livros, cabe destacar a sua trilogia sobre a ideia de revelação no contexto da pós-modernidade: Deus liberans (1996), El Dios escondido (2010) e Deus ineffabilis (2015).

Como sair das malhas da violência intersubjetiva? É a pergunta que abre o círculo hermenêutico da "teologia niilista da temporalidade messiânica", isto é, uma teologia da fraqueza do mistério de Deus que se revela na temporalidade messiânica (CALDEIRA, 2017a, p. 42). De fato, a crescente "espiral de violência" ${ }^{8}$ que assola a humanidade, coloca como centro da reflexão pós-moderna o problema da intersubjetividade como tarefa histórica. Enquanto alguns pensadores propõem o retorno à metafísica como resolução do enigma da violência intersubjetiva em sua dimensão planetária, outros assumem o desafio de "pensar a comunhão humana possível, enquanto comunidade de indivíduos diferentes, suscetível de viver em sociedade", sem renunciar o caminho da intersubjetividade para resolver a questão do mútuo reconhecimento (MENDOZA, 2007b, p. 100-104).

O correlato teológico da questão da intersubjetividade é a pergunta da teodiceia: "Por que Deus permite o sofrimento no mundo e, ao mesmo tempo, se diz todo-poderoso e bom?" Trata-se, com efeito, do enigma do mal no mundo e a maneira cristã de sair das malhas da violência. Em diálogo com a teologia pragmática de Peuket, no pensamento teológico de Carlos Mendoza a ênfase não recai apenas sobre o mal no mundo, antes sobre o seu reverso, capaz de suscitar a esperança; pois se existe uma saída para a humanidade - que se debate entre rivalidade e doação - esta passa pelo fundo existencial das vítimas e dos justos da história (MENDOZA, 2010a, p. 239). Ora, esse fundo existencial, isto é, a realidade antropológica reconciliada, viabiliza o acesso ao fundo teologal do real e a possibilidade de vivencia do mistério transcendente do real.

E, na interlocução com o niilismo pós-moderno e o pensamento antissistêmico, Carlos Mendoza procura dar conta de dizer Deus e o humano no contexto da pós-modernidade em termos de "escaton", isto é, o tempo pleno além e aquém da temporalidade cronológica (MENDOZA, 2007a, p. 15-52). Trata-se da contribuição da inteligência teológica ao espaço intersubjetivo como fides quaerens gratuitatem, isto é, como intelecção da experiência da linguagem da fé da subjetividade pós-moderna que acolhe a revelação divina inspirada pela heurística da gratuidade como estágio da comunhão fraterna e sorora plenamente realizado (MENDOZA, 2010a, p. 350).

\footnotetext{
${ }^{8}$ Essa expressão "espiral de violência" [montée aux extremes] advém da leitura antropológica do real que realiza René Girard, que através da teoria do desejo mimético constata que o real é religioso e sacrificial; e por isso, violento. Neste artigo, todas as citações literais de Carlos Mendoza serão tradução nossa.
} 
Destacamos, assim, dois aspectos dessa antropologia teológica niilista sob o horizonte kenótico: a) a subjetividade radicalmente aberta; b) a escuta cordial do murmúrio das vítimas.

\subsection{Subjetividade vulnerável aberta à alteridade e à transcendência}

Para dar conta de dizer a relação humano-divino e compreender como acontece a redenção no contexto da pós-modernidade, Carlos Mendoza propõe um fecundo diálogo com o niilismo pós-moderno na aposta pela irreversível autonomia da razão e sua existência agônica sem, contudo, negar a surpreendente gratuidade da revelação divina.

Diferente do pensamento ontoteológico que fala do "realismo epistemológico", o niilismo pós-moderno fala de um "realismo ontológico", de uma existência vivida até os limites de si mesmo: "além da essência" até o "último suspiro" (MENDOZA, 2008, p. 21). Essa perspectiva de vulnerabilidade condensa-se na expressão "sujeito vulnerável", cunhada na esteira dos pós-modernos desconstrucionistas, sobretudo com Gianni Vattimo, Jacques Derrida e Jean-Luc Nancy. Trata-se da experiência do sujeito desencantado dos metarrelatos, que assume a exclusão como lugar hermenêutico e político. Um sujeito que descobre a si mesmo e os demais por meio de uma apercepção inusitada, própria do poder-do-não poder, aprendendo a viver na provisoriedade, no relento da existência nua, sem complacência, nem fundamento, nem sentido, apenas um si-mesmo aberto aos outros e ao mundo (MENDOZA, 2010a, p. 169-195). Nessa experiência niilista:

A partir da assunção da própria vulnerabilidade, o sujeito débil começa a mostrar outro rosto para além da aparência anódina que o etiquetava em uma primeira impressão. Assim começa a gênesis de uma presença para si mesmo de caráter proativo, marcada pela tomada de distância diante dos sistemas de totalidade e sua influência nos mecanismos da própria subjetividade (MENDOZA, 2010a, p. 171-172).

Inicia-se assim a descrição da subjetividade pós-moderna em sua constitutiva vulnerabilidade e abertura para o outro como modo de estar-no-mundo ${ }^{9}$, com vistas à justificação do estatuto imanente da construção do sentido salvífico para a humanidade. Entretanto, contata-se que não basta à subjetividade o desencanto dos metarrelatos, típico do sujeito vulnerável. Faz-se necessário à subjetividade passar pela desconstrução para que, desencantada de todo metarrelato e desconstruída de todo desejo de onipotência, ela alcance o seu estágio mais radical de abertura a tudo o que existe. Essa abertura

${ }^{9}$ Para uma descrição da fenomenologia da subjetividade moderna e pós-moderna na perspectiva do teólogo mexicano, cf. CALDEIRA, 2017b, p. 810-833. 
radical da subjetividade torna-se possível com J-L. Nancy, visto que ele acrescenta à desconstrução derridariana ${ }^{10}$ a perspectiva mística por meio da ideia de "declosión"11. A "declosión" é um neologismo para falar da redução fenomenológica do cristianismo até chegar a sua essência kenótica. "Declosión", pois, está relacionada à ideia de desenclaurusamento, reabertura daquilo que foi fechado (NANCY, 2008, p. 15).

Por isso, a "declosión" torna-se a principal categoria para interpretar a subjetividade vulnerável em tempos pós-modernos, visto que o niilismo místico possibilita desvendar o novo estágio da subjetividade, que se revela como o "último estágio da encarnação do Logos na história do Ocidente" (MENDOZA, 2015a, p. 66). Em sentido fenomenológico, trata-se da descrição do aprofundamento da inteligibilidade do sentido da subjetividade vulnerável que se sabe capaz de "mudar o mundo", isto é, da experiência de subjetivação das vítimas e dos justos da história capaz de parar em sua própria carnalidade a "espiral de violência", que coloca em risco o futuro da humanidade e do planeta.

A subjetividade "declosionada", marcada que está pela indigência (MENDOZA, 2015a, p. 66), designa o estágio da subjetividade radicalmente aberta a tudo o que existe, cuja única certeza é saber-se "habitada pela presença de alteridade que é fonte da relação criadora de sentido" (MENDOZA, 2010a, p. 226). Depois de passar pela crítica niilista, a subjetividade esvaziada chega ao umbral do horizonte escatológico do real - horizonte que o cristianismo se apresenta como portador e indicador - sob a dinâmica da doação (MENDOZA, 2010c, p. 137).

Entretanto, somente com a recepção criativa da teoria do desejo mimético de René Girard pela teologia que se acessa a subjetividade em "chave de desejo como doação". Nisto consiste a novidade da análise do desejo de René Girard, pois ela afirma a "complexa exterioridade fundante" da subjetividade, isto é, a forma histórica de ser-no-mundo reside na estrutura mimética da subjetividade (MENDOZA, 2015a, p. 362). Ela diz respeito ao reconhecimento de um terceiro que influencia na configuração do objeto do desejo. Esse terceiro se expressa tanto no modelo que se imita como no próprio objeto desejado. A análise desse mecanismo fundante da sub-

\footnotetext{
${ }^{10}$ Jean-Luc Nancy foi amigo e discípulo de Derrida, que é considerado o "pai" da desconstrução. Para uma aproximação a proposta desconstrucionista sob a ótica da teologia pós-moderna, cf. MENDOZA, 2010a, p. 165-224.

${ }^{11}$ A "declosión" é o processo de desconstrução do cristianismo como origem do Ocidente enquanto narrativa niilista da kénosis que funda o Ocidente. Um abaixamento divino que acontece desde a criação do universo e se consuma na encarnação do Logos divino. De forma que somente num a-teísmo será possível pensar este estágio atual da razão ocidental, visto que o despojo divino implica a renúncia da razão ao poder de toda representação, rito e símbolo que tenha por pretensão esgotar a "origem sem origem" que é Deus em linguagem monoteísta (MENDOZA, 2015a, p. 469).
} 
jetividade chama-se teoria do desejo mimético, que possibilita a Carlos Mendoza alcançar a percepção fundamental do desejo antisacrificial da subjetividade exposta e em doação. Sob essa dinâmica antisacrificial como uma realidade antropológica-teologal instaura-se a nova temporalidade messiânica, isto é, a intersubjetividade, abrindo a possibilidade de reconciliação e paz no seio da história violenta e conflitiva.

De posse, pois, dessa chave hermenêutica da subjetividade vulnerável pós-moderna, de modo sapiencial o teólogo mexicano passa a escutar o "murmúrio das vítimas" e discernir nele o lugar por excelência da passagem do Mistério Amoroso do Real, que em linguagem monoteísta chama-se Deus. Nesta perspectiva da subjetividade vulnerável pós-moderna, messias é todo justo da história que consegue superar a lógica da rivalidade e oferecer-se como dom a outrem sob a dinâmica da gratuidade.

\subsection{Escuta cordial do murmúrio das vítimas}

Herdeiro da tradição libertadora da América Latina, o frei dominicano está inteiramente comprometido com o sofrimento dos pobres e excluídos no contexto da exclusão global. Partindo da mediação da fenomenologia, ele situa no murmúrio das vítimas e excluídos o lugar por excelência da revelação divina; por meio dela ele afirma a impossibilidade de percepção do Mistério Amoroso do Real fora do marco da negatividade da subjetividade e da história. Para ele a "história dos vencidos [...] é o rastro de transcendência na imanência da história" (MENDOZA, 1996, p. 101). E por meio de uma "estética teológica da negatividade" ${ }^{12}$ se propugna a desvendar os rostos dos "novos pobres" e suas potências de experiência como lugar sócio-teologal.

O murmúrio dos inocentes não apenas é um imperativo ético-político, senão que é também princípio de conhecimento do real, de percepção estética originária do mundo e, desde aí, uma possibilidade fontal de abertura à transcendência na vida mística própria da fé teologal, desnuda, sem ataduras (MENDOZA, 2012, p. 27).

$\mathrm{Na}$ interlocução com a teoria do desejo mimético de René Girard, Carlos Mendoza assume o conceito de "vítimas sistêmicas"13, para falar das subjetividades vulneráveis e vulnerada da história, ampliando significativamente

\footnotetext{
12 Para aproximar-se dessa "estética da negatividade", ver: MENDOZA, C. A. Deus liberans. La revelación cristiana en diálogo con la modernidad. Los elementos fundacionales de la estética teológica. Fribourg: Éditions Universitaires, 1996.

13 Vítimas sistêmicas são aquelas pessoas que não são contadas como protagonistas na economia sustentável, pois não passam de dígitos do estado de pobreza planetário. São todas as excluídas e os excluídos pelos sistemas de totalidade. Mais especificamente, são as vítimas produzidas pela violência mimética em suas diversas facetas de invisibilização social (MENDOZA, 2014b, p. 390).
} 
o alcance da categoria "pobre", tão preciosa à teologia da libertação. Nesse novo contexto, seguindo a escatologia do teólogo britânico James Alison em sua recepção criativa à teoria do desejo mimético, ele afirma: as vítimas "são os novos rostos de Abel, o justo, que é sacrificado pelo desejo mimético de seu irmão Caim. A vítima inocente é aqui a vítima mais indefesa que transgride a ordem da dominação por meio de uma resistência criativa" (MENDOZA, 2016b, p. 275-276), fazendo de sua própria carnalidade o lugar da passagem da lógica da rivalidade à lógica da doação.

Com a assunção da ruptura epistemológica do Sul (SOUSA SANTOS; MENESES, 2009), o teólogo mexicano aponta a "racionalidade messiânica" como a única capaz de justificar as resistências e resiliência dos povos originários, das mulheres, dos negros e negras, dos indígenas, das minorias sexuais, etc., como "patrimônio espiritual e místico da humanidade" capaz de transformar o real violento e instaurar o estágio harmonioso da intersubjetividade (MENDOZA, 2017, p. 76-80). São as resistências múltiplas enquanto práticas e narrativas outras, que instauram um mundo mais justo e compassivo e, portanto, abrem caminho histórico de esperança para as vítimas.

Sob o marco do "desejo mimético de doação", tais resistências múltiplas como gestos de extrema gratuidade das vítimas da história encarnam a concreção histórica dessa vulnerabilidade constitutiva da subjetividade. Ora, essa experiência de gratuidade amorosa das vítimas da história é experiência teologal, que precisa ser esquadrinhada.

Longe de propor um novo metarrelato a partir das vítimas (MENDOZA, 2010a, p. 316), o teólogo mexicano afirma a possibilidade de elas tornarem-se "expressão histórica do absoluto", na medida em que perdoam a seus verdugos (MENDOZA, 2014a, p. 79-92). Reabilitar, pois, a experiência teologal das vítimas é desvendar o caminho da transcendência a partir da experiência do perdão recebido e oferecido gratuitamente.

Significa que na escuta cordial do murmúrio das vítimas se pode captar o sentido último da história que se encontra na lógica da gratuidade, capaz de ultrapassar os muros da rivalidade e do ressentimento por meio da oferenda do perdão (MENDOZA, 2012, p. 19-33). Nesse sentido, o chamado teologal da manifestação do murmúrio que vem de Deus advém da "mediação desta existência agônica vivida pelas vítimas da história - e em particular e de modo sumo pelo Crucificado que se entrega como oferenda da possibilidade de encontrar-se com o outro" (MENDOZA, 2010a, p. 329). Com efeito, a entrega assimétrica das vítimas da história é já "antecipação kairológica" da redenção no coração da história conflitiva da humanidade, por meio do perdão oferecido gratuitamente.

Se trata de uma ordem do real somente visível para o olhar da fé na luz obscura da revelação. Uma ordem do real própria da esperança que luta 
conta toda esperança. Uma ordem do real, ao fim e ao cabo, de um incessante processo de doação amorosa que somente é perceptível "mais além do ressentimento", na força que emana do ágape do Messias (MENDOZA, 2015a, p. 438-439).

Nessa perspectiva, a existência em doação dos justos revela a gratuidade do amor incondicional e superabundante de Deus e, ao mesmo tempo, assinala o advento da temporalidade redimida de sua violência fraticida e sororicida. É evidente que a história permanece ancorada nos processos de rivalidade e violência, entretanto, a possibilidade de transcendê-la está na existência em doação dos justos e das vítimas da história, na medida em que fazem do perdão a sua habitação.

Conclui-se, pois, que a escuta do murmúrio divino passa pela experiência teologal dos processos de subjetivação que realiza as vítimas da história. Esse processo de constituição da identidade relacional, isto é, da reconstituição da subjetividade em sua significação messiânica [aquela que imita o desejo de Cristo], designa a vida vivida como experiência da temporalidade messiânica e kairológica que Cristo inaugurou ao aparecer como vítima perdoadora e oferecer-se como per-dón à comunidade de discípulas e discípulos.

Nesse processo de constituição da existência autêntica, as vidas dos justos e das vítimas sem ressentimento tornam-se o locus theologicus do amor incondicional do Deus ineffabilis em seu ser Superabundante e Superessencial (MENDOZA, 2015a, p. 415). Eles e elas não somente aprendem a habitar a sua exclusão na heurística da "(im)potência potente" ${ }^{14}$, isto é, do desejo redimido de sua violência, mas também inserem na história, por meio do gesto messiânico do perdão, o tempo messiânico como lugar do mútuo reconhecimento na gratuidade.

\section{A modo de conclusão}

Neste contexto de derrubamento da cristandade e a urgente necessidade de dizer Deus e o humano em meio à violência intersubjetiva em escala planetária, percebe-se que estas antropologias da vulnerabilidade ensaiam cada uma a seu modo e contexto específico - um balbucio sobre o Mistério Amoroso do Real. João Duque discorre sobre a experiência de vulnerabilidade no contexto da modernidade tardia, na crítica da racionalidade que

14 "Impotência potente" é uma glossa nossa ao "poder do não-poder" de Carlos Mendoza, que procede da gratuidade amorosa, cujo sentido denota o mimetismo depurado de sua rivalidade. Quando o Messias Jesus aparece como "vítima perdoadora" ele revela que o núcleo da subjetividade unida à temporalidade escatológico é sua "impotência potente". 
se projeta sobre o real com uma vontade de poder; o real representado na própria corporeidade do humano com a intensão de dominá-la e superá-la. Para o teólogo lusitano, a redenção passa pela assunção de uma teologia política da encarnação, que seja capaz de acolher a si mesmo e o outro em sua vulnerabilidade constitutiva. Uma teologia política da encarnação torna-se indispensável para dar conta de acolher as diferenças. Entretanto, parece que essa teologia política não resolve ainda o problema das pulsões de destruição e morte de toda a subjetividade, mesmo aquela que assumiu a sua vulnerabilidade constitutiva. Assim, o problema da violência intersubjetiva em escala global parece que fica ainda irresoluto. E mais, parece que ainda as alteridades negadas permanecem invisibilizadas e sem voz.

Carlos Mendoza, por sua vez, assume esse aspecto da constitutiva vulnerabilidade da subjetividade aberta à alteridade, mas vai além da modernidade tardia, isto é, ele vai além da crítica ao ego moderno. Assim, ao inserir a subjetividade vulnerável na crítica niilista, depara-se com a subjetividade esvaziada e radicalmente aberta à alteridade e à transcendência, sem fundamento, cuja única certeza é saber-se habitada pela Alteridade amorosa; que a habilita a viver a sua exclusão sob a dinâmica da gratuidade. A subjetividade vulnerável pós-moderna aparece, assim, em sua autoconsciência de finitude e destituída de sua vontade de poder, como subjetividade aberta e em doação.

Na intersecção entre racionalidade pós-moderna e pensamento antissistêmico, ele se aproxima das alteridades negadas pela racionalidade moderna e, assim, passa a escutar o murmúrio das vítimas e inocentes como chamado teologal e teológico. E descobre, pois, na vida dos justos e das vítimas da história a concreção histórica desta subjetividade radicalmente aberta a tudo o que existe, que vivem a exclusão com criatividade.

Nessa atitude sapiencial, ele interpreta teologicamente as múltiplas resistências das vítimas e dos inocentes da história como autêntico mover da Ruah divina, que redime a história por meio dos gestos messiânicos advindos dos gestos de extrema gratuidade em meio a história violenta da humanidade. Em outras palavras, diferente da teologia tradicional que busca a segurança do fundamento metafísico do real e, assim, a afirmação da ação intervencionista de Deus na história, uma teologia da fraqueza do mistério de Deus interpreta os gestos de extrema doação das vítimas que perdoam como a ação do Espírito do Crucificado-que-vive. Com isso, o teólogo mexicano ensaia responder ao drama da violência no espaço público com a afirmação de que Deus escuta o grito da vítima, isto é, que a experiência cristã de Deus possível em tempos de fragmentos passa pelo esvaziamento/kénosis da subjetividade e na acolhida às vítimas da história.

Por fim, reconhecemos que tanto a teologia política da encarnação quanto a teologia kenótica nos colocam em rota de conversão, em direção à 
construção de nossa comum e única humanidade. Entretanto, sinalizamos o "esquecimento da colonialidade" de ambas análises da subjetividade, como vem denunciando o pensamento decolonial, de modo especial Nelson Maldonado-Torres (2008, p. 73). Trata-se da necessidade de assumir a ruptura epistemológica decolonial e incluir nas análises da subjetividade a fenomenologia do damné, o sujeito racializado e negado em sua humanidade, para ensaiar uma resposta teológica ao drama da violência intersubjetiva estruturada no racismo epistêmico e ontológico, que ameaça o futuro da humanidade e do planeta. Evidentemente, a decolonização não era propósito dos autores apresentados, mas é imprescindível a sua assunção, como ambos já vêm sinalizando em suas pesquisas mais recentes e ainda não publicadas.

\section{Referências}

APPEL, Kurt. Apprezzare la morte: cristianesimo e nuovo umanesimo. Bologna: EDB, 2015.

CALDEIRA, Cleusa. Tempo messiânico e sacramentalidade da subjetividade vulnerável na obra de Carlos Mendoza Alvarez. 299 p. Tese (Doutorado em Teologia) - Faculdade Jesuíta de Filosofia e Teologia, Belo Horizonte, 2017a.

. Teologia e niilismo pós-moderno. A subjetividade vulnerável como locus theologicus no pensamento de Carlos Mendoza Álvarez. Pistis \& Praxis, Curitiba, v. 9 , n. 3, p. $810-833,2017 b$.

CRUZ, Maria Teresa. A histeria do corpo. Revista de Comunicação e Linguagens, Lisboa, n. 28, p. 363-375, 2000.

DUQUE, João Manuel. Dizer Deus na pós-modernidade. Lisboa: Alcalá, 2003.

. O excesso do dom. Lisboa: Alcalá, 2004.

. A transparência do conceito: estudos para uma metafísica teológica. Lisboa: Didaskalia, 2010.

Do sentimento de si ao sentimento do outro. Theologica, Braga, v. 46, n. 1, p. 15-29, 2011.

. Fragmentos para uma filosofia da hospitalidade. In: CAPPELLANO DOS SANTOS, M. M.; BAPTISTA, I. (Org.). Laços sociais: por uma epistemologia da hospitalidade. Caxias do Sul: Educs, 2014. p. 149-160.

. Fraternidade originária. Da violência mimética à responsabilidade pelo outro. Forma Breve, Aveiro, n. 12, p. 71-78, 2015.

Utopias neo-gnósticas do pós-humano na cibercultura. Para uma leitura filosófico-teológica. Perspectiva Teológica, Belo Horizonte, v. 48, n. 1, p. 163-182, jan./abr. 2016a.

Para o diálogo com a pós-modernidade. São Paulo: Paulus, 2016b. 
. El Dios ocultado. Salamanca: Sígueme, 2017a.

Hospitalidade e violência. Sobre um possível fundamento religioso anterior ao estado laico. Franciscanum, Bogotá, v. 59, n. 167, p. 195-213, 2017 b.

GIRARD, René; CHANTRE, Benoît. Rematar Clausewitz: além da guerra. São Paulo: É Realizações, 2011.

MALDONADO-TORRES, Nelson. A topologia do Ser e a geopolítica do conhecimento. Modernidade, império e colonialidade. Revista Crítica de Ciências Sociais, Coimbra, n. 80, p. 71-114, 2008.

MENDOZA ÁlVAREZ, Carlos. Deus liberans. La revelación cristiana en diálogo con la modernidad. Los elementos fundacionales de la estética teológica. Fribourg: Éditions Universitaires, 1996.

Dios es inútil. Por una desconstrucción de las imágenes de Dios. In: HEREDIA J.; ZUBIRÍA G. (Coords.). Imágenes de Dios en el mundo contemporâneo. México: UITCAM, 2007a. p. 15-52.

. El colapso del sujeto posmoderno: nihilismo y mística. In: MENDOZA ÁLVAREZ, Carlos (Coord.). Subjetividad y experiencia religiosa pós-moderna. México: Universidad Iberoamericana, 2007b. p. 81-113.

Entre nihilismo y vuelta al fundamento. In: MENDOZA ÁLVAREZ, Carlos (coord.). ¿Cristianismo posmoderno o postsecular? Por una interpretación teológica de la modernidad tardía. México: Universidad Iberoamericana, 2008. p. 17-36.

El Dios escondido de la posmodernidad. Deseo, memoria e imaginación escatológica. Ensayo de teología fundamental posmoderna. Guadalajara: SUJ, 2010a.

Subjetividad posmoderna e identidad reconciliada. Una recepción teológica de la teoría mimética. Revista Universitas Philosophica, Bogotá, v. 27, n. 55, p. 149$158,2010 b$.

Teología y razón autónoma. Un debate epistemológico con la Radical Orthodoxy. In: LEGORRETA J. J. (coord.). Religión y secularización en una sociedad postsecular. México: Universidad Iberoamericana, 2010c. p. 121-150.

Teología de la reconciliación en clave mimético-pragmática. In.: MENDOZA ÁLVAREZ, Carlos (Org.). La participación de los cristianos en la construcción del espacio público.México: Universidad Iberoamericana, 2011. p. 199-212.

"Vivir hasta la muerte". Reflexión filosófico-teológica sobre la compasión. Ciencia Tomista, t. 139, n. 447, p. 19-33, 2012.

Extra victimas salus non est. O de la vigencia de la teología de la liberación en tiempos pós-modernos. In: BRIGHENTI, A.; HERMANO, R. 50 años de Vaticano II. Análisis y perspectivas. Memorias del Congreso Continental de Teología, Unisinos, Brasil, 07-11 de octubre de 2012. Bogotá: Ediciones Paulinas, 2013. p. 192-203.

. De las márgenes al centro vacío. Aportes de la posmodernidad a la teología de la liberación. EATWOT's International Theological Commission, v. 37, n. 4, p. 81-92, 2014a.

. Escatología y apocalipsis en tiempos posmodernos. Concilium 356, v. 50, n. 3, p. 387-398, 2014b. 
Deus ineffabilis: una teología posmoderna de la revelación del fin de los tiempos. Barcelona: Herder/Universidad Iberoamericana, 2015a.

La recepción del Concilio Vaticano II en América Latina. El caso de la teología de la revelación. In: BRIGHENTI, A.; MERLOS, F. O Concilio Vaticano II Batalha Perdida Ou Esperança Renovada. São Paulo: Paulinas, 2015b. p. 265-287.

El papel de la existencia kairológica como crítica al sistema hegemónico y a la violencia global. In: GODOY, J. M. (Org.). Tempos do Espírito: inspiração e discernimento. Belo Horizonte/Sao Paulo: SOTER/Paulinas, 2016a. p. 31-42.

La teología de la liberación en contexto pós-moderno en América Latina y Caribe. Perspectiva Teológica, Belo Horizonte, v. 48, n. 2, p. 269-288, 2016b.

MOLTMANN, Jürgen. Theologie der Hoffnung. In: BAUER, Johannes B. (Hrg.). Entwürfe der Theologie. Graz: Styria, 1985. p. 235-257.

NANCY, Jean-Luc. La déclosión. Buenos Aires: La Cebra, 2008. (Deconstrucción del cristianismo, 1).

SOUSA SANTO, Boaventura; MENEZES, Maria Paula. Epistemologias do Sul. Coimbra: Almedina, 2009.

Artigo submetido em 09.03.2018 e aprovado em 30.07.2018.

Cleusa Caldeira é pós-doutoranda em teologia pela Pontifícia Universidade Católica do Paraná (PUC-PR), doutora em Teologia pela Faculdade Jesuíta de Filosofia e Teologia (FAJE), Belo Horizonte (2017). Professora colaboradora no Programa de Pós-Graduação em Teologia Sistemática da PUC-PR. Bolsista CAPES. Orcid.org/0000-0001-7202-0682. E-mail: cleucaldeira@gmail.com

Endereço: Rua Sanito Rocha, 225 - Apto. 706

Cristo Rei Curitiba - PR

CEP 80050-380 